Neurological Disorders in Famous Artists 


\section{Frontiers of Neurology and Neuroscience}

\section{Vol. 19}

Series Editor

J. Bogousslavsky Lausanne 


\section{Neurological Disorders in Famous Artists}

Volume Editors

J. Bogousslavsky Lausanne

F. Boller Paris

38 figures, 14 in color, and 3 tables, 2005

KARGER $\quad \begin{aligned} & \text { Basel } \cdot \text { Freiburg } \cdot \text { Paris } \cdot \text { London } \cdot \text { New York } \\ & \text { Bangalore } \cdot \text { Bangkok } \cdot \text { Singapore } \cdot \text { Tokyo } \cdot \text { Sydney }\end{aligned}$ 
Prof. Julien Bogousslavsky
Department of Neurology
CHUV
CH-1011 Lausanne (Switzerland)

\author{
Prof. François Boller \\ INSERM Unit 549 \\ Centre Paul Broca \\ FR-75014 Paris (France)
}

\author{
Library of Congress Cataloging-in-Publication Data \\ Neurological disorders in famous artists / volume editors, J. Bogousslavsky, \\ F. Boller. \\ p. ; cm. - (Frontiers of neurology and neuroscience ; v. 19) \\ Includes bibliographical references and index. \\ ISBN 3-8055-7914-4 (hardcover : alk. paper) \\ 1. Nervous system-Diseases 2. Artists-Diseases \\ [DNLM: 1. Famous Persons-Case Reports. 2. Nervous System Diseases-Case \\ Reports. ] I. Bogousslavsky, Julien. II. Boller, François. III. Series. \\ RC359.N46 2005 \\ $616.8-\mathrm{dc} 22$ \\ 2005002444
}

Bibliographic Indices. This publication is listed in bibliographic services, including Current Contents ${ }^{\circledR}$ and Index Medicus.

Drug Dosage. The authors and the publisher have exerted every effort to ensure that drug selection and dosage set forth in this text are in accord with current recommendations and practice at the time of publication. However, in view of ongoing research, changes in government regulations, and the constant flow of information relating to drug therapy and drug reactions, the reader is urged to check the package insert for each drug for any change in indications and dosage and for added warnings and precautions. This is particularly important when the recommended agent is a new and/or infrequently employed drug.

All rights reserved. No part of this publication may be translated into other languages, reproduced or utilized in any form or by any means electronic or mechanical, including photocopying, recording, microcopying, or by any information storage and retrieval system, without permission in writing from the publisher.

(C) Copyright 2005 by S. Karger AG, P.O. Box, CH-4009 Basel (Switzerland)

www.karger.com

Printed in Switzerland on acid-free paper by Reinhardt Druck, Basel

ISSN 1660-4431

ISBN 3-8055-7914-4 


\section{Contents}

VII Preface

1 Guillaume Apollinaire, the Lover Assassinated Bogousslavsky, J. (Lausanne)

9 Guy de Maupassant and Friedrich Nietzsche. A Comparison of Two Cases of 19th-Century General Paresis

Hayden, D. (San Anselmo, Calif.)

17 The One-Man Band of Pain. Alphonse Daudet and His Painful Experience of Tabes dorsalis Dieguez, S.; Bogousslavsky, J. (Lausanne)

46 Gustave Flaubert's Hidden Sickness Jallon, P. (Geneva); Jallon, H. (Paris)

57 Edgar Allan Poe: Substance Abuse versus Epilepsy Bazil, C.W. (New York, N.Y.)

65 Dostoevsky and Epilepsy: An Attempt to Look Through the Frame Rossetti, A.O. (Boston, Mass.); Bogousslavsky, J. (Lausanne)

76 Immanuel Kant: Evolution from a Personality 'Disorder' to a Dementia

Guard, O.; Boller, F. (Paris)

85 Valery Larbaud

Boller, F. (Paris) 
92 Alajouanine's Painter: Paul-Elie Gernez

Boller, F. (Paris)

101 Carolus Horn - When the Images in the Brain Decay. Evidence of

Backward-Development of Visual and Cognitive Functions in Alzheimer's Disease

Maurer, K.; Prvulovic, D. (Frankfurt)

112 Major Depression and Stroke in Caspar David Friedrich

Dahlenburg, B.; Spitzer, C. (Greifswald)

121 Understanding Van Gogh's Night: Bipolar Disorder

Carota, A. (Lausanne); Iaria, G. (Rome); Berney, A.;

Bogousslavsky, J. (Lausanne)

132 The Terminal IIIness and Last Compositions of Maurice Ravel Baeck, E. (Antwerp)

141 The Decay and Death of Modest Musorgsky

Baeck, E. (Antwerp)

150 Georg Friedrich Händel's Strokes

Bäzner, H.; Hennerici, M. (Mannheim)

160 The Subcortical Vascular Encephalopathy of Joseph Haydn - Pathographic Illustration of the Syndrome

Bäzner, H.; Hennerici, M. (Mannheim)

172 Music and the Brain: Gershwin and Shebalin

Ruiz, E.; Montañés, P. (Bogotá)

179 Robert Schumann's Focal Dystonia

Altenmüller, E. (Hannover)

189 Author Index

190 Subject Index 


\section{Preface}

Art, creativity and neurology may seem widely different topics at first sight. However, it is obvious that art originates in the brain. Therefore, disorders of the nervous system often influence the preparation and development of artistic activities because they may alter motor, sensory, and above all, cognitive, functions.

The creativity of painters, musicians, writers, poets, and other artists is the magnified expression of one of the 'highest' brain functions in the human being, and it is understandable that brain, spinal cord, or peripheral nerve disease may have subtle or overt influences on artistic production. While every clinician has indeed observed instances of altered or modified creative abilities in individual patients with acute or chronic neurological disease, one of the best ways to address the problem probably is to have a closer look at famous artists, whose activity and production has changed (or has failed to do so) after the development of a lesion or dysfunction of the nervous system.

In the following chapters, the impact of various neurological diseases such as stroke, epilepsy, brain trauma, dementia, and other problems in famous artists (writers, philosophers, painters, and composers) is presented through the lens of changes in their behavior and in their production. Some 'cases' such as Ravel or van Gogh are already famous, but the nature of their disease has remained somewhat controversial. Other artists with a neurological disorder have been much less well studied, including Apollinaire, Daudet, Gernez, Haydn, or Kant, to quote only a few.

There is no such a thing as a 'creativity center' in the brain, and the production of an art work obviously requires a 'global' brain functioning, about which we are still lacking much knowledge. However, it is also striking to observe how a localized damage to the brain or other nervous structures has led 
to subtle or dramatic changes in creativity and artistic production in many famous artists. Between 'neurology of history' and 'history of neurology', the study of how a neurological disorder can alter productivity in recognized artists and other creative people is a largely unexplored field. We hope that this book will represent a useful contribution to this domain.

Julien Bogousslavsky François Boller 